\title{
Determination of Cadmium in Urine and Observations on Urinary Cadmium and Protein Excretion in Men Exposed to Cadmium Oxide Dust
}

\author{
By J. C. SMITH, J. E. KENCH AND R. E. LANE \\ Nuffield Department of Occupational Health, University of Manchester
}

(Received 27 May 1955)

Prolonged exposure of workmen in the alkalineaccumulator industry to cadmium oxide dust led in many cases to the appearance of protein in the urine (Friberg, 1950). As part of a study of the proteinuria of cadmium poisoning an accurate method for the measurement of cadmium in urine was obligatory. This paper describes a sensitive and specific dithizone procedure and presents data on the incidence and degree of proteinuria in relation to cadmium exposure and excretion.

\section{MATERIALS AND METHODS}

Fresh urinary specimens of 120 employees in an alkalineaccumulator factory were examined for the presence of protein as follows: $2 \mathrm{ml} .25 \%(\mathrm{w} / \mathrm{v})$ trichloroacetic acid were added to $2 \mathrm{ml}$. urine that had first been filtered until clear. A just perceptible opalescence was recorded as a trace $( \pm)$, definite opacity as positive $(+)$ and a precipitate as strongly positive $(++)$. Twenty-five urinary specimens gave evidence of the presence of protein by this sensitive test, and the positive specimens also showed heat coagulation, precipitation by $25 \%(\mathrm{w} / \mathrm{v})$ salicylosulphonic acid and Esbach's and Heller's Tests.

Urinary specimens from twelve workmen offered the possibility of more detailed study. Mid-morning specimens from these men were transported weekly to the laboratory with minimal delay for quantitative evaluation of cadmium and protein. A group of 100 workmen of similar age range without known exposure to cadmium were used as controls.

Total urinary protein. Total urinary protein was determined by the biuret method of Hiller, McIntosh \& Van Slyke (1927), using $40 \mathrm{ml}$. urine instead of $2 \mathrm{ml}$. as in the original procedure.

Concentration of the urine. Creatinine concentration was determined by the alkaline picrate method of Bonsnes \& Taussky (1945). Specific gravity was measured by weighing the urine in a calibrated $50 \mathrm{ml}$. volumetric flask corrected for temperature.

\section{Cadmium in urine}

Earlier reports of cadmium excretion (Princi, 1947; Cotter \& Cotter, 1951) indicated that a suitable method should measure $0-20 \mu \mathrm{g}$. Cd in $50 \mathrm{ml}$. urine and be sensitive to $0 \cdot 1 \mu \mathrm{g}$. Cd. A colorimetric procedure using diphenylthiocarbazone appeared most likely to fulfil these conditions.

Numerous dithizone methods for Cd have been described, based on the original observation of Fischer \& Leopoldi
(1937) that the cadmium-dithizone complex in $\mathrm{CHCl}_{3}$ solution is stable on treatment with $6 \% \mathrm{NaOH}$. The procedure of Setterlind \& Krause (1943) for determination of $\mathrm{Cd}$ in air appeared capable of application to biological material without major modification.

In early trials with this method it was found that $0-40 \mu \mathrm{g}$. Cd in aqueous solution could be recovered quantitatively in the presence of $1000 \mu \mathrm{g}$. of each of the following metal ions: $\mathrm{Ag}^{+}, \mathrm{Al}^{3+}, \mathrm{Ba}^{2+}, \mathrm{Bi}^{2+}, \mathrm{Ca}^{2+}, \mathrm{Co}^{2+}, \mathrm{Cr}^{3+}, \mathrm{Fe}^{3+}$, $\mathrm{Mn}^{2+}, \mathrm{Pb}^{2+}, \mathrm{Sn}^{2+}$, and $\mathrm{Sn}^{4+}$, but that quantities of $\mathrm{Cu}^{2+}$ and $\mathrm{Hg}^{2+}$ greater than 200 and $30 \mu \mathrm{g}$. respectively prevented recovery of $\mathrm{Cd}$. Interference from $\mathrm{Cu}$ and $\mathrm{Hg}$ could be avoided by a preliminary extraction of these metals from approximately $1 \% \mathrm{HNO}_{3}$ with $\mathrm{CHCl}_{3}$ and dithizone.

Further experience in the application of the method to measurement of $\mathrm{Cd}$ in urine showed that a number of changes were necessary. The following points are worthy of special mention: (1) For final measurement of Cd the pink dithizone complex is to be preferred to the green dithizone solution in $\mathrm{CHCl}_{3}$ regenerated from the complex, since the dithizone solution is photolabile. (2) Considerable losses of Cd occurred during the two washings with $6 \% \mathrm{NaOH}$. Such losses could be prevented by dropwise addition of a $1.5 \%(w / v) \mathrm{NH}_{3}$ solution of dithizone to maintain an excess of dithizone in the aqueous layer. This effect could be ascribed to an equilibrium between dithizone in the aqueous phase and the complex in $\mathrm{CHCl}_{3}$. Great excess of dithizone resulted in the passage of $\mathrm{Pb}$ along with $\mathrm{Cd}$ as dithizonates into the $\mathrm{CHCl}_{3}$ layer. Eventually the dithizone was employed entirely in $\mathrm{NH}_{3}$ solution and the $\mathrm{CHCl}_{3}$ added without dithizone in solution. In addition, the blank colour was thereby reduced considerably having been formerly somewhat yellow due to the presence of a decomposition product of dithizone. (3) The amount of KCN $(0 \cdot 25 \%)$ used by Setterlind \& Krause in the second alkaline washing was insufficient to prevent interference by a large excess of $\mathrm{Pb}$. The observation of Saltzman (1953) that the presence of cyanide in the first alkaline washing generally reduced interference from other metals, mainly $\mathrm{Pb}$, was confirmed. The concentrations of cyanide employed by Saltzman (0.05 and $1.0 \%$ for the first and second washing respectively) were adopted and were found to be satisfactory. (4) The acid digests of urine contained much $\left(\mathrm{NH}_{4}\right)_{2} \mathrm{SO}_{4}$ formed from urea and other urinary nitrogen compounds. When $\mathrm{NaOH}$ was added to the neutralized digest in the first alkaline washing, $\mathrm{NH}_{3}$ was evolved with equivalent loss of alkali and no control over the $\mathrm{pH}$ of the aqueous phase was possible. This difficulty was avoided by neutralizing the digest with conc. $\mathrm{NH}_{3}$ (sp.gr. 0.880) and making a preliminary extraction of trace metals from weakly ammoniacal solution with dithizone and $\mathrm{CHCl}_{3}$. 
The reagents and method finally employed are as follows.

Reagents. Water distilled and stored in Pyrex glassware was used in the preparation of all aqueous solutions. All the reagents used were of Analar quality.

Sodium hydroxide $40 \%$-potassium cyanide $0.05 \%$ : 80 g. $\mathrm{NaOH}$ pellets and $0 \cdot 1 \mathrm{~g}$. A.R. KCN were dissolved in $200 \mathrm{ml}$. distilled water.

Sodium hydroxide $40 \%$-potassium cyanide $1.0 \%$ : $80 \mathrm{~g}$. $\mathrm{NaOH}$ pellets and $2 \cdot 0 \mathrm{~g}$. KCN were dissolved in $200 \mathrm{ml}$. distilled water; both these solutions are renewed after 7 days.

Sodium potassium tartrate solution $25 \%(w / v)$; this is also renewed after 7 days.

Ammonia solution $1.5 \%(\mathrm{w} / \mathrm{v}): 25 \mathrm{ml}$. conc. $\mathrm{NH}_{3}$ (sp.gr. 0.880) were diluted to $500 \mathrm{ml}$. with distilled water.

Nitric acid solution $1 \%(\mathrm{w} / \mathrm{v}): 20 \mathrm{ml}$. $\mathrm{HNO}_{3}$ (sp.gr. 1.42) were diluted to $2000 \mathrm{ml}$. with distilled water.

Ammoniacal dithizone was prepared by dissolving approximately $0.1 \mathrm{~g}$. diphenylthiocarbazone

$$
\left(\mathrm{C}_{6} \mathrm{H}_{5}-\mathrm{N}=\mathrm{N}-\mathrm{CS}-\mathrm{NH}-\mathrm{NH}-\mathrm{C}_{6} \mathrm{H}_{5}\right)
$$

in $10 \mathrm{ml}$. $\mathrm{CHCl}_{3}$ and extracting the solution with $20 \mathrm{ml}$. $1.5 \% \mathrm{NH}_{3}$ solution. The $\mathrm{CHCl}_{3}$ layer was run off completely from the orange-red ammoniacal layer.

A stock standard Cd solution was prepared by dissolving $0 \cdot 2032 \mathrm{~g}$. $\mathrm{CdCl}_{2}, 2 \cdot 5 \mathrm{H}_{2} \mathrm{O}$, previously dried in a desiccator, in $1000 \mathrm{ml} .1 \%$ nitric acid. This solution contained $100 \mu \mathrm{g}$. $\mathrm{Cd} / \mathrm{ml}$. A working standard solution containing $1 \mu \mathrm{g}$. $\mathrm{Cd} / \mathrm{ml}$. was prepared as required by diluting $10 \mathrm{ml}$. of the stock solution to $1000 \mathrm{ml}$. with $1 \%$ nitric acid.

The reagent blank for the complete procedure was found to be so low $(0 \cdot 3 \mu \mathrm{g}$. $\mathrm{Cd})$ that removal of $\mathrm{Cd}$ from the reagents was unnecessary.

Three $250 \mathrm{ml}$. Pyrex pear-shaped separatory funnels were employed. These were cleaned twice with hot tap water and rinsed twice with distilled water after each analysis.

Method. $50 \mathrm{ml}$. urine were measured in a graduated flask and transferred to a $100 \mathrm{ml}$. Pyrex Erlenmeyer flask. Any deposit was stirred thoroughly into the urine before measuring. Transfer was completed by two washings with distilled water. The urine was evaporated gently to dryness on a sand bath. The flask was then allowed to cool and $5 \mathrm{ml}$. conc. $\mathrm{HNO}_{3}$ were added, the flask being further warmed on the sand bath until the evolution of brown fumes had ceased. After cooling, $4 \mathrm{ml}$. conc. $\mathrm{H}_{2} \mathrm{SO}_{4}$ were added and the flask was heated more strongly to evaporate the $\mathrm{HNO}_{3}$. At this stage the blackened digest was allowed to cool, treated with $0.5 \mathrm{ml}$. 100-vol. $\mathrm{H}_{2} \mathrm{O}_{2}$ and then warmed gently. The addition of $\mathrm{H}_{2} \mathrm{O}_{2}$ was repeated two or three times until the digest remained clear after strong heating.

The digest was allowed to cool and diluted with $10 \mathrm{ml}$. distilled water and approx. $1 \mathrm{~g}$. sodium citrate added. The sodium citrate prevented the formation of a precipitate (presumed to be calcium phosphate) which otherwise formed on neutralization. The contents of the flask were rendered just alkaline to litmus by addition of conc. $\mathrm{NH}_{3}$ (sp.gr. 0.880). The neutralized digest was cooled and transferred to a separatory funnel. The flask was rinsed out with two $5 \mathrm{ml}$. portions of $1 \% \mathrm{HNO}_{3}$ and the washings were added to the funnel. A further $5 \mathrm{ml} .1 .5 \% \mathrm{NH}_{3}$ solution were added, together with $10 \mathrm{ml}$. $\mathrm{CHCl}_{3}$ and ten drops of ammoniacal dithizone. The funnel was shaken and more dithizone was added until, after shaking, the $\mathrm{CHCl}_{3}$ layer became dark blue in colour. The coloured extract, containing the dithizonates of most of the trace metals including $\mathrm{Cd}$ together with excess of dithizone, was run off into a second funnel containing $25 \mathrm{ml} .1 \% \mathrm{HNO}_{3}$. Further,

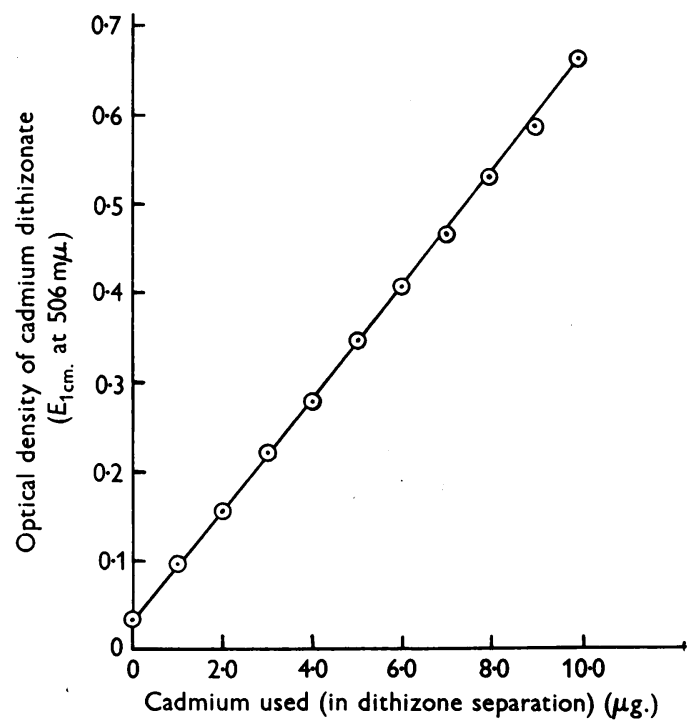

Fig. 1. Relation between the amount of cadmium and the optical density of its derived dithizonate, measured in chloroform $(10 \mathrm{ml}$.) at $506 \mathrm{~m} \mu$.

\section{Table 1. Recovery of cadmium added to normal urine}

The cadmium was added to $50 \mathrm{ml}$. samples of urine. Columns I and II show duplicate values.

\begin{tabular}{|c|c|c|c|c|}
\hline \multirow[b]{3}{*}{ Added } & \multicolumn{4}{|c|}{ Amount of cadmium ( $\mu \mathrm{g})}$. \\
\hline & \multicolumn{2}{|c|}{ Found } & \multicolumn{2}{|c|}{ Recovered } \\
\hline & I & II & $\mathbf{I}$ & II \\
\hline $0 \cdot 0$ & 0.5 & 0.5 & 0.0 & $0 \cdot 0$ \\
\hline $1 \cdot 0$ & $1 \cdot 6$ & 1.4 & $1 \cdot 1$ & 0.9 \\
\hline $2 \cdot 0$ & $2 \cdot 6$ & $2 \cdot 5$ & $2 \cdot 1$ & $2 \cdot 0$ \\
\hline $3 \cdot 0$ & $3 \cdot 7$ & $3 \cdot 5$ & $3 \cdot 2$ & 3.0 \\
\hline $4 \cdot 0$ & 4.5 & $4 \cdot 3$ & $4 \cdot 0$ & $3 \cdot 8$ \\
\hline $5 \cdot 0$ & $5 \cdot 3$ & 5.4 & $4 \cdot 8$ & $4 \cdot 9$ \\
\hline $10 \cdot 0$ & $10 \cdot 8$ & $10 \cdot 7$ & $10 \cdot 3$ & $10 \cdot 2$ \\
\hline
\end{tabular}

similar extractions were made until the $\mathrm{CHCl}_{3}$ became green. After shaking the pooled $\mathrm{CHCl}_{3}$ extracts with $1 \%$ $\mathrm{HNO}_{3}$, the $\mathrm{CHCl}_{3}$ layer, containing $\mathrm{Cu}$ and $\mathrm{Hg}$, was discarded. The last traces of green dithizone colour were removed with $5 \mathrm{ml}$. $\mathrm{CHCl}_{3}$, added gently and run off without shaking.

The aqueous layer, which contained $\mathrm{Cd}$ and the other trace metals whose dithizonates were unstable in the presence of dilute acid, was rendered strongly alkaline 
with $5 \mathrm{ml} .40 \% \mathrm{NaOH}-0.05 \% \mathrm{KCN}$, and $2 \mathrm{ml} .25 \%$ sodium potassium tartrate, $10 \mathrm{ml}$. $\mathrm{CHCl}_{3}$ and five drops of ammoniacal dithizone were added. The mixture was shaken for $1 \mathrm{~min}$. and then allowed to stand. If the aqueous layer was colourless or only pale yellow on settling further dithizone was added and the funnel was shaken again. The pink $\mathrm{CHCl}_{3}$ layer containing only $\mathrm{Cd}$ and traces of $\mathrm{Pb}$ as their dithizonates was run into a third separatory funnel containing $25 \mathrm{ml} .1 \% \mathrm{HNO}_{3}$. The contents of the second funnel were further extracted with $10 \mathrm{ml}$. portions of $\mathrm{CHCl}_{3}$ until the extracts were colourless, three such extractions being normally sufficient to remove the largest quantity of Cd encountered.

The third funnel was then shaken for $1 \mathrm{~min}$. to decompose the complexes, the $\mathrm{Cd}$ and $\mathrm{Pb}$ entering the aqueous phase. The pale green $\mathrm{CHCl}_{3}$ layer was discarded and the last traces of dithizone removed by adding $5 \mathrm{ml}$. $\mathrm{CHCl}_{3}$, which were run off without shaking. To the aqueous layer were added $5 \mathrm{ml} .40 \% \mathrm{NaOH}-1 \% \mathrm{KCN}$ and $5 \mathrm{ml}$. $\mathrm{CHCl}_{3}$. Three drops of ammoniacal dithizone were added and the mixture was shaken for $1 \mathrm{~min}$. With large quantities of $\mathrm{Cd}$ further addition of dithizone was necessary to ensure that the aqueous layer remained yellow in colour. The pink $\mathrm{CHCl}_{3}$ layer, containing only cadmium dithizonate, was withdrawn into a graduated tube and the extraction was repeated with a further $5 \mathrm{ml}$. $\mathrm{CHCl}_{3}$. A few drops of $\mathrm{CHCl}_{3}$ were used to remove the last traces of complex. The volume in the tube was brought to $10 \mathrm{ml}$. with $\mathrm{CHCl}_{3}$ and the tube was stoppered and allowed to stand, when most of the water droplets entrained in the $\mathrm{CHCl}_{3}$ settled out on the walls of the tube. The optical density of the cadmium dithizonate was measured at its maximum, $506 \mathrm{~m} \mu$., in a Unicam spectrophotometer SP. 500. The time of standing was not critical as the cadmium complex was photostable.

Normally twelve urines with two blanks were digested and analysed together and the final $\mathrm{CHCl}_{3}$ solutions stood for about an hour before the measurement of the absorption. Cadmium contents of the various specimens were read from a standard curve prepared by passing accurately measured volumes of the working standard Cd solution through the analytical procedure. The standard curve is shown in Fig. 1. The reagent blank for the complete determination was consistently $\mathbf{0 \cdot 3} \boldsymbol{\mu \mathrm { g }}$. Recoveries of $\mathrm{Cd}$ added to normal urine are presented in Table 1.

\section{RESULTS}

The data on the incidence of proteinuria in this study are presented in Table 2. Proteinuria was observed in $5 \%$ of the control group of workers, whereas $20 \%$ of the workers exposed to cadmium showed urinary protein. The normal range of urinary cadmium was found to be $0-20 \mu \mathrm{g} . / 1$., and the range in the workmen exposed to cadmium was $10-580 \mu \mathrm{g} . / 1$.

The results of cadmium and protein determinations over a period of 6 weeks on weekly spot samples from twelve workers are shown in Table 3. Specific gravity and creatinine values are included as a guide to the concentration of the specimens. No attempt has been made to employ these values to correct the cadmium and protein excretions for variations from normal urinary concentration.

Cadmium in air determinations in the plant were made during the period February-July 1952. The mean values for the two main processes carried out in the plant were 0.33 and $0.55 \mathrm{mg}$. $\mathrm{Cd} / \mathrm{m} .^{3}$ with the highest figure $1.9 \mathrm{mg} . / \mathrm{m}^{3}$. Many of the workmen studied had been subjected for many years to

Table 2. Incidence of proteinuria in workers exposed to cadmium and in workers without known exposure

The total number of exposed workers tested was 120 and the total number tested, but not exposed, was 100. The amount of protein excreted is designated as follows: ++ +, approx. 5 g./l.; + +, approx. 1 g./l.; +, 0.1-1 g./l.; \pm , 25-100 mg./l.; negative, <25 mg./l.

\begin{tabular}{ccc} 
Degree of & \multicolumn{2}{c}{ Number of workers } \\
proteinuria & $\overbrace{\text { Exposed }}$ & Not exposed \\
++ & 0 & 1 \\
++ & 1 & 0 \\
+ & 17 & 1 \\
\pm & 7 & 3 \\
Negative & 95 & 95
\end{tabular}

conditions worse than this. The various processes were graded 0-4, and an exposure index, a measure of the atmospheric cadmium in the individuals working life, was computed by summation of the products of process grading and time of exposure (in years) for all the work done.

\section{DISCUSSION}

The subjects of this study have been exposed to cadmium oxide dust for periods varying from 0 to 30 years, the severity of exposure likewise differing widely throughout the group. There was no clear relationship between grading of exposure and urinary cadmium, especially on the least hazardous operation (Table 3).

Proteinuria occurred more frequently in cadmium workers than in the control group (Table 2), although in all exposed cases the quantity of protein was small. Urinary cadmium and excreted protein appeared to vary independently, but workman $\mathbf{A}$, who worked in a severely contaminated atmosphere, consistently excreted most cadmium and protein in his urine. Currently exposed workmen (D, H, J, K, L, P and R) generally exhibited higher rates of urinary cadmium excretion than those not currently exposed (M, $O$ and $Q$ ), whilst the values for $N$, who had not been in contact with cadmium oxide dust, were within the normal range. The nature of the proteinuria in this intoxication is the subject of continued study. 
Table 3. Urinary excretion of cadmium and protein in workmen exposed to cadmium oxide dust

The urine of each workman was tested weekly for six successive weeks (urines 1-6). For definition of exposure rating and exposure index see text.

\begin{tabular}{|c|c|c|c|c|c|c|c|c|c|c|c|c|}
\hline Workman ... & $\mathbf{A}$ & D & $\mathbf{H}$ & $\mathbf{J}$ & $\mathbf{K}$ & $\mathbf{L}$ & $\mathbf{M}$ & $\mathbf{N}$ & 0 & $\mathbf{P}$ & $\mathbf{Q}$ & $\mathbf{R}$ \\
\hline \multicolumn{13}{|l|}{ Exposure } \\
\hline Current rating & 4 & 2 & 2 & 1 & 1 & 1 & 0 & $\mathbf{0}$ & $\mathbf{0}$ & 1 & $\mathbf{0}$ & 2 \\
\hline Time (years) & 15 & 30 & 15 & 26 & 30 & 25 & 22 & 0 & 14 & 30 & 25 & 10 \\
\hline Index & 53 & 83 & 28 & 44 & 53 & 43 & 66 & 0 & 22 & 30 & 16 & 16 \\
\hline \multicolumn{13}{|l|}{ Urine 1} \\
\hline Cd ( $\mu \mathrm{g} . / 1)$. & 578 & 98 & 122 & 52 & 90 & 114 & 36 & 22 & 40 & 76 & 10 & 42 \\
\hline Protein (mg./l.) & 1138 & 170 & - & 383 & 738 & 575 & 400 & 0 & 10 & 15 & 5 & 25 \\
\hline Sp.gr. & $1 \cdot 020$ & $1 \cdot 021$ & $1 \cdot 023$ & $1 \cdot 028$ & $1 \cdot 020$ & $1 \cdot 022$ & $1 \cdot 017$ & $1 \cdot 027$ & $1 \cdot 024$ & $1 \cdot 023$ & $1 \cdot 015$ & $1 \cdot 023$ \\
\hline \multicolumn{13}{|l|}{ Urine 2} \\
\hline $\mathrm{Cd}(\mu \mathrm{g} \cdot / 1)$. & 500 & 56 & 80 & 41 & 54 & 20 & 32 & 10 & 44 & 52 & - & 28 \\
\hline Protein (mg./l.) & 925 & 320 & 13 & 40 & 195 & 103 & 125 & 10 & 15 & 8 & - & 183 \\
\hline Sp.gr. & $1 \cdot 021$ & 1.019 & 1.020 & $1 \cdot 027$ & $1 \cdot 012$ & $1 \cdot 009$ & $1 \cdot 028$ & $1 \cdot 019$ & $1 \cdot 024$ & 1.019 & - & $1 \cdot 023$ \\
\hline Creatinine (mg./100 ml.) & - & 98 & 82 & 44 & 62 & 32 & 160 & 99 & - & 153 & - & 125 \\
\hline \multicolumn{13}{|l|}{ Urine 3} \\
\hline Cd ( $\mu \mathrm{g} . / 1)$. & 534 & 50 & 40 & 42 & 66 & 76 & 32 & 12 & 30 & 84 & 15 & 37 \\
\hline Protein (mg./l.) & 575 & & 25 & 55 & 83 & 75 & 393 & $\mathbf{0}$ & 0 & 45 & 15 & 10 \\
\hline Sp.gr. & $1 \cdot 021$ & $1 \cdot 014$ & $1 \cdot 013$ & $1 \cdot 030$ & $1 \cdot 018$ & $1 \cdot 019$ & $1 \cdot 019$ & $1 \cdot 024$ & $1 \cdot 021$ & $1 \cdot 023$ & $1 \cdot 019$ & $1 \cdot 025$ \\
\hline Creatinine (mg./100 ml.) & 97 & 61 & 20 & 58 & 122 & 109 & 116 & 154 & 111 & 174 & 92 & 129 \\
\hline \multicolumn{13}{|l|}{ Urine 4} \\
\hline Cd ( $\mu \mathrm{g} . / 1)$. & $\mathbf{3 3 5}$ & 20 & 139 & 36 & 62 & 38 & - & 10 & 一 & 26 & 12 & 18 \\
\hline Protein (mg./l.) & 1283 & 48 & 43 & 500 & 1300 & 508 & 563 & $\mathbf{0}$ & - & 25 & 10 & $\mathbf{0}$ \\
\hline Sp.gr. & $1 \cdot 019$ & $1 \cdot 017$ & $1 \cdot 024$ & $1 \cdot 024$ & $1 \cdot 019$ & $1 \cdot 010$ & - & $1 \cdot 022$ & - & 1.021 & 1.017 & $1 \cdot 023$ \\
\hline Creatinine (mg./100 ml.) & 76 & 80 & 134 & 34 & 128 & $\mathbf{3 0}$ & 112 & 122 & 一 & 144 & 91 & 105 \\
\hline \multicolumn{13}{|l|}{ Urine 5} \\
\hline $\mathrm{Cd}(\mu \mathrm{g} . / 1)$. & 一 & 56 & 38 & 36 & 78 & 104 & 24 & 9 & 37 & 27 & 13 & 16 \\
\hline Protein (mg./l.) & - & 100 & 28 & 638 & 1005 & 678 & 1128 & 0 & 10 & 10 & 10 & 0 \\
\hline Sp.gr: . & - & $1 \cdot 017$ & $1 \cdot 011$ & $1 \cdot 026$ & $1 \cdot 015$ & $1 \cdot 017$ & $1 \cdot 020$ & $1 \cdot 011$ & - & $1 \cdot 017$ & $1 \cdot 021$ & $1 \cdot 017$ \\
\hline Creatinine (mg./100 ml.) & - & 56 & 19 & 20 & 72 & 86 & $\mathbf{5 0}$ & 26 & 168 & 135 & 82 & 43 \\
\hline \multicolumn{13}{|l|}{ Urine 6} \\
\hline $\mathrm{Cd}(\mu \mathrm{g} . / 1)$. & - & 76 & 132 & 34 & 76 & 44 & 26 & 12 & 20 & 48 & 10 & 28 \\
\hline Protein (mg./l:) & - & 80 & & 600 & 1270 & 520 & 780 & 0 & 15 & 10 & 0 & $\mathbf{0}$ \\
\hline Sp.gr. & - & $1 \cdot 017$ & $1 \cdot 025$ & $1 \cdot 024$ & $1 \cdot 019$ & $1 \cdot 010$ & - & $1 \cdot 010$ & $1 \cdot 020$ & $1 \cdot 020$ & $1 \cdot 012$ & $1 \cdot 019$ \\
\hline Creatinine (mg./100 ml.) & - & 148 & 164 & 86 & 159 & 84 & 132 & 174 & 120 & 160 & 79 & 180 \\
\hline
\end{tabular}

\section{SUMMARY}

1. An accurate, sensitive and reliable method for the determination of cadmium in urine has been evolved.

2. The incidence of proteinuria in a group of workers exposed to cadmium oxide dust was higher than in controls.

3. Urinary cadmium and protein appeared to vary independently.

We are grateful to $\mathrm{Mr} \mathbf{H}$. V. Stevenson for valuable practical assistance and to Dr R. S. F. Schilling who kindly arranged for men under his care to act as controls. The investigation was made possible by the co-operation of Alkaline Batteries Ltd. to whom one of us (J.C.S.) is also indebted for financial support.

\section{REFERENCES}

Bonsnes, R. W. \& Taussky, H. H. (1945). J. biol. Chem. 158, 581.

Cotter, L. H. \& Cotter, B. H. (1951). A.M.A. Arch. industr. Hyg. 3, 495.

Fischer, H. \& Leopoldi, G. (1937). Mikrochem. Acta, 1, 30.

Friberg, L. (1950). Acta med. scand. 138, Suppl. 240, 1.

Hiller, A., McIntosh, J. F. \& Van Slyke, D. D. (1927). J. clin. Invest. 4, 25.

Princi, J. (1947). J. industr. Hyg. 29, 315.

Saltzman, B. E. (1953). Analyt. Chem. 25, 493.

Setterlind, A. N. \& Krause, A. H. (1943). Micro-analysis of Cadmium by the Diphenylthiocarbazone (Dithizone) Method. Illinois: Dept. Publ. Health, Div. industr. Hyg. 